\title{
Hemophagocytic syndrome: pitfalls in its diagnosis
}

\author{
Department of Internal Medicine Faculty of Medicine \\ Department of Pathology, Faculty of Medicine, State University of Campinas - Campinas, Brazil
}

The hemophagocytic syndrome (HS) is characterized by a clinical picture of fever, hepatosplenomegaly, lymphadenopathy and peripheral pancytopenia. The morphologic hallmark of this syndrome is the phagocytosis of hematopoietic elements by morphologically normal macrophages. HS is considered rare and may be a primary disease or associated to viral, infection, neoplasias or autoimmune diseases. Treatment is controversial and its evolution is often fatal. Anatomo-pathological evaluation shows the phenomenon of hemophagocytosis in several organs, especially the hematopoietic tissues. We describe a case of HS, discuss its possible causes, its clinical and pathologic features, its pathophysiology and therapeutic possibilities.

UNITERMS: Hemophagocytic Syndrome. Lymphohistiocytosis. pancytopenia.

\section{INTRODUCTION}

$\mathrm{H}$ emophagocytic syndrome has been described as a disorder of morphologically normal macrophages. The clinical features are fever, hepatosplenomegaly, lymphoadenopathy and pancytopenia, secondary to a phenomenon of phagocytosis of hematological elements and their precursors in bone marrow and peripheral lymphoid organs $s^{1,2,3}$. This syndrome has been associated to viral infections, especially the EpsteinBarr virus, cytomegalovirus and adenovirus. In this context it has been called "virus-associated hemophagocytic syndrome" (VAHS). There are reports associating HS with

\section{Address for correspondence:}

Cármino Antonio de Souza

Cidade Universitária "Zeferino Vaz" - P.O. Box 6198

Campinas/SP - Brasil - CEP 13081-970 infections caused by bacteria, mycobacteria, fungi and parasites as well as carcinomas and lymphomas, mainly of $\mathrm{T}$ cells ${ }^{12,4.5}$. HS may occur in young children as an isolated disease named hemophagocytic lymphohistiocytosis ${ }^{2,6}$.

HS may also be associated with other diseases, such as systemic lupus erythematosus, Weber-Christian disease, sarcoidosis and drug-induced agranulocytosis ${ }^{1,2,3}$.

Although phagocytosis of hemopoietic precursors by macrophages in bone marrow is not uncommon, HS is considered rare $^{2}$. Its incidence may be higher in a referral hospital and its diagnosis requires attention ${ }^{3}$.

The main laboratory changes found in HS demonstrate progressive systemic involvement. According to the guidelines of the Hystiocyte Society its diagnosis comprises fever, splenomegaly, bicytopenia or pancytopenia (seen in $75 \%$ of the patients) hypeitrigliceridemia and hemophagocytosis in bone marrow. Coagulation tests show progressive abnormalities including hypofibrinogenemia. Transaminase values and inflammatory tests are also altered. Serologic and rheumatologic examinations are useful for discarding associated diseases ${ }^{2,3,7}$. 
The anatomo-pathological evaluation of the many organs involved shows the phenomenon of hemophagocytosis by morphologically normal macrophages, in bone marrow, liver, spleen and lymph nodes. It may also be found in the meninges or the skin $^{2,3}$.

The pathophysiology is quite unclear, but probably a variety of cytokines are involved. Some specific events may start an uncontrolled activation of the cellular immune system. Through the release of IFN gamma and IL-2, cytotoxic T-lymphocytes and CD8 + lymphocytes activate the macrophage cytokines, especially TNF, PGF2 alpha, PGE2 and IL6. These cytokines show specific and interactive functions and lead to clinical manifestations of fever, coagulopathy, lipidic changes, phagocytosis, anemia, leukopenia and thrombocytopenia. Macrophagic activation also leads to hyperferritinemia and alterations of lipidic enzymes.

\section{CASE REPORT}

E.A.G.S., a 19-year-old white male, presented a history of two months with ecchymosis and gingivorrhagia. No other signs and symptoms were found. He had been treated for idiopathic thrombocytopenic purpura (ITP) six years earlier. Physical examination showed a young man in a good general condition, except for petechiae and ecchymosis. Hemoglobin: 14,3 g/dl; MCV $83 \mathrm{fl}$; $\mathrm{MCH}$ $26 \mathrm{pg}$; leukocytes: $5,1 \times 10^{9} /$, with $62 \%$ polymorphonuclear neutrophils, $4 \%$ eosinophils, $2 \%$ basophils, $27 \%$ lymphocytes and $5 \%$ monocytes; platelets: $5 \times 10 \%$. Screening coagulation tests were normal. Bone marrow cytology showed unspecific alterations. Prednisone $1 \mathrm{mg} /$ $\mathrm{kg}$ was introduced, considering a diagnostic hypothesis of ITP.

One week later, the patient presented fever and cellulitis in the right limb. Blood counts remained unchanged. The patient was hospitalized and treated with antibiotics. Laboratory tests for renal and hepatic functions were normal. The serology for HIV 1 and HIV 2, hepatitis $\mathrm{B}$, hepatitis C virus, cytomegalovirus and Epstein-Barr virus, as well as syphilis and toxoplasmosis, were negative. LE cells, Anti-Ro(SSA), Anti-Sm, Anti-la(SSb), AntiRNP, Anti-DNA and antiphospholipid antibodies were negative. Chest X-ray and transthoracic echocardiogram were normal. A slightly enlarged liver and spleen were found by abdominal ultra-sound.

Bone marrow cytology and histology showed increased cellularity, dyserythropoiesis and a slight decrease in granulocytic precursors, a slight increase in the megacaryocytic series and frequent macrophages showing hemophagocytosis. Immunohistochemical stain for UCHL-1, L26 and lysozyme were performed in order to exclude bone marrow involvement by lymphoma. Immunostain by lysozyme showed clearly the large number of macrophages with hemophagocytosis (fig.1). Cytogenetic analysis showed a $46 \mathrm{XY}$ karyotype.

Ten days later, hemoglobin was $11,0 \mathrm{~g} / \mathrm{dl}$, hematocrit $34 \%$, leukocytes $1,1 \times 10^{9} / 1$ (35\% segmented neutrophils, $60 \%$ lymphocytes and $5 \%$ monocytes) and platelets $2 \times 10 \%$ 1. Blood biochemistry remained normal. Hepatosplenomegaly had increased. Bone marrow biopsy was repeated but findings remained unchanged. A new investigation for viruses, bacteria, mycobacteria and fungi was performed but no agent was isolated. After 15 days, the chest X-ray showed a diffuse interstitial infiltrate. The patient presented abdominal distention and abdominal ultra-sonography and tomography showed a moderate enlargement of spleen and liver. Then, the patient progressed to coma, and presented clinical and laboratory features of consumption coagulopathy. CT of the skull was normal. Cerebrospinal fluid evaluation showed proteinorrhachia of $81 \mathrm{mg} / \mathrm{dl}$, with no other changes. The electroencephalogram was compatible with diffuse encephalopathy. Despite receiving intensive care, the patient died in a few days. An autopsy was performed. The main necroscopical findings were: intensely hypercellular bone marrow with moderate increase in erythroblasts, increase in more immature granulopoietic precursors and intense histiocytosis with hemophagocytosis (fig. 1); the liver showed slight, focal portal lymphohistiocytic infiltration, and hyperplasia of Kupffer cells with moderate hemophagocytosis (fig. 2); lymph nodes showed normal architecture but had an

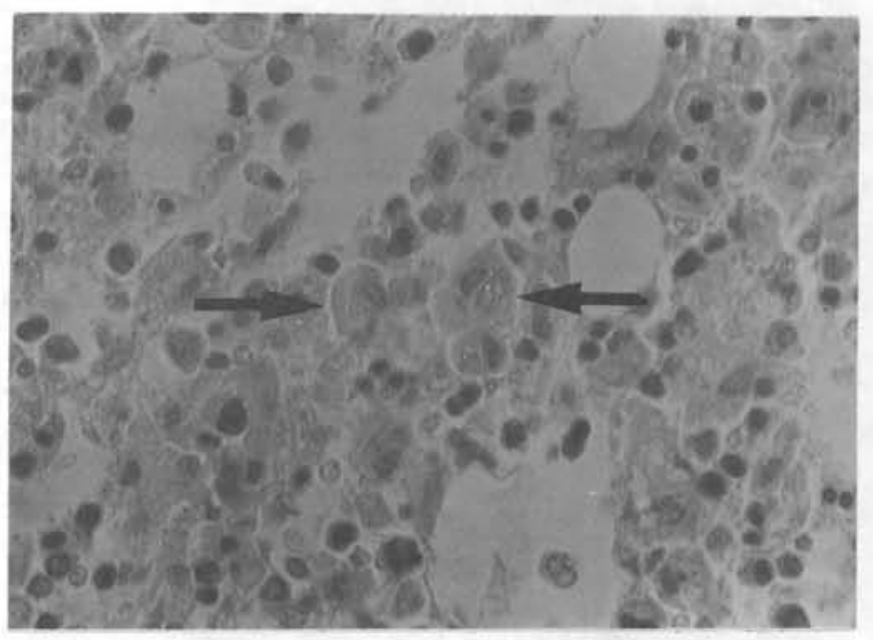

Figure 1-Bone marrow with hemophagocytosis (arrows). A- HE, x 600. B- Immunostain with lysozyme, x 400 . 
3); spleen showed myeloid metaplasia and hemophagocytosis. Diffuse alveolar injury (initial phase) and hemorrhagic bronchopneumonia were found in the lungs. The brain presented focal subarachnoid hemorrhage and meningeal lymphohistiocytic infiltration.

\section{DISCUSSION}

Hemophagocytosis is defined as a condition in which the phagocytosis of hemopoietic precursor cells by macrophages of normal appearance is observed in bone marrow, lymph nodes, spleen or liver. This phenomenon may occur in a variety of clinical states, including familial hemophagocytic lymphohistiocytosis, viral infections and malignant histiocytosis, as well as some types of malignant lymphomas ${ }^{1.23 .5}$.

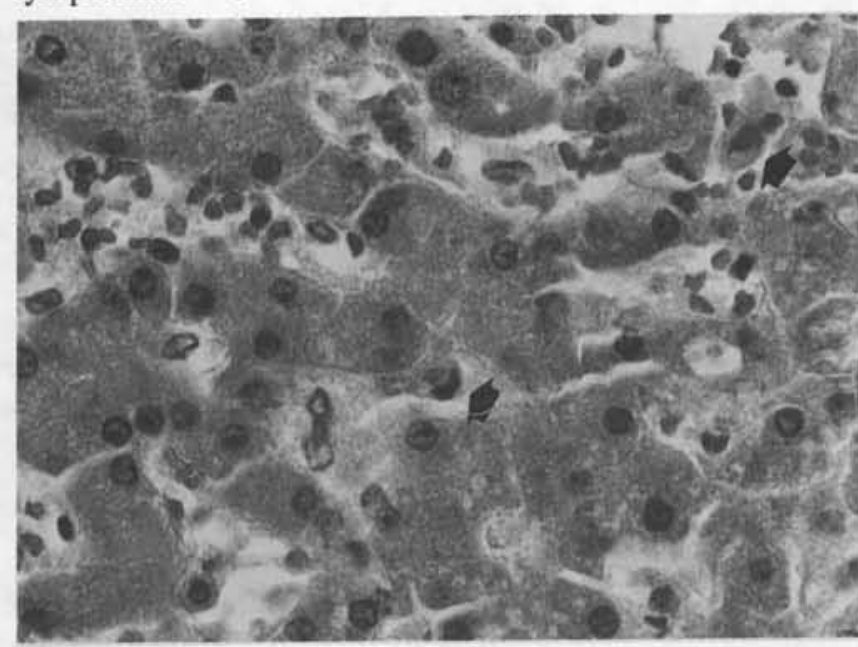

Figure 2 - Liver showing hyperplasia of Kupffer cells with hemophagocytosis (arrows). HE, x 600.

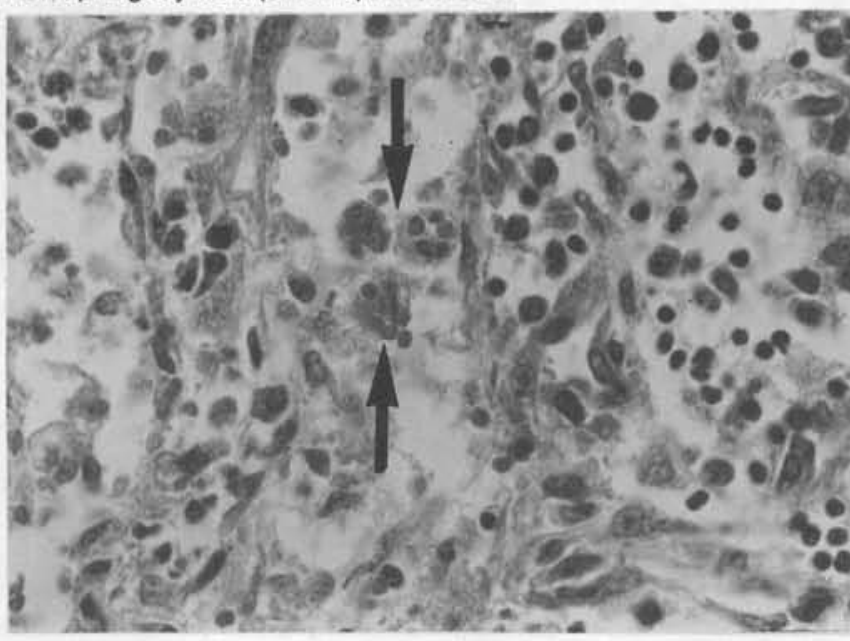

Figure 3 - Lymph node with hemophagocytosis (arrows). HE, x 600
The term hemophagocytic lymphohistiocytosis includes the familiar, sporadic and virus-associated hemophagocytic forms ${ }^{2}$. The familiar form of hemophagocytic lymphohistiocytosis probably has a recessive autosomal origin. It is also known as familiar hemophagocytic reticulosis, Farquhar's disease, familiar erythrophagocytic lymphohistiocytosis, lymphohistiocytic reticulosis with phagocytosis, or lymphohistiocytosis. Its incidence is 1.2 cases per million children under 15 years ${ }^{2}$. Most cases are no older than three. Evolution is similar to a septic picture but with no detectable etiologic agent. Laboratory tests frequently reveal hypertriglyceridemia and hypofibrinogenemia. Cytopathologic evaluation shows phagocytosis of blood elements by macrophages and an increased number of atypical lymphocytes in bone marrow, spleen, liver, lymph nodes, skin and cerebrospinal fluid. The disease shows a non-responsive and rapid clinical course and may be treated with chemotherapy (epipodophylotoxins) or cyclosporin A, with a response in some cases. Nevertheless, frequently there is a relapse within some years. Bone marrow transplantation has been another therapeutical option, but long term evaluation is not available ${ }^{2,89}$.

Virus-associated hemophagocytic syndrome (V.A.H.S.) was first described in immunodeficient patients ${ }^{7}$, in whom previously described findings were associated to viral infections. More recently it has been observed in immunocompetent patients. The main viruses involved are Epstein-Barr virus, cytomegalovirus, adenovirus and parvovirus B19. The clinical course is often fatal, despite specific treatment for infection and for hemophagocytic syndrome with immunosuppressive drugs. The hemophagocytic syndrome, described in HIV positive patients, is generally associated with other viruses, especially the Epstein-Barr virus, or to other infections ${ }^{2,3,7,10}$.

Secondary hemophagocytic syndrome occurs in infections by Gram-negative bacteria, tuberculosis, kalaazar and fungi ${ }^{11,14}$. It was also observed in patients with $\mathrm{T}$ cell lymphomas, in some cases with the presence of the Epstein-Barr virus ${ }^{11,12,13}$.

Hemophagocytic syndrome has been described in other diseases: in Weber-Christian's disease (as a histiocytic cytophagic panniculitis $)^{7}$; in the advanced phase of ChediakHigashi's syndrome'; in systemic lupus erythematosus ${ }^{7}$ and in patients receiving parenteral feeding with a high lipid content ${ }^{2}$. There is a report of a very successful treatment of Weber-Christian's disease with cyclosporin $\mathrm{A}^{7}$.

The pathophysiology of the hemophagocytic syndrome is still unclear, although there is evidence that several cytokines (mainly IL2, PGE2, PGF2 ${ }^{\mathrm{a}}$, IFNg and TNF) are associated with the phenomenon or its triggering. The fact 
that some cases responded to therapy with cyclosporin A suggests a dysfunction of T lymphocytes and NK cells in the pathogenesis of macrophage activation ${ }^{25,6,8}$.

In the present case, the initial manifestation was pancytopenia and the only alterations we found were dyserythropoesis and the presence of hemophagocytosis in bone marrow. There was no evidence of a family history. Initially, ITP was hypothesized but the use of corticosteroids did not result in an increase of platelets. Instead, the disease progressed with pancytopenia and an increase in hepatosplenomegaly and fever. Serological and molecular tests failed to demonstrate a bacterial or viral infection. Cell atypias were found in all three hemopoietic cell lines, suggesting the diagnosis of myelodysplastic syndrome, but significant hemophagocytosis is not usually found in this condition. Immunohistochemistry was used to exclude bone marrow involvement by lymphoma. This technique was also important in demonstrating the extent of the macrophage hyperplasia, and in confirming the diagnosis of the hemophagocytic syndrome.
The patient did not show any evidence of a rheumatologic disorder, neoplasia or a congenital disease. The clinical evolution was similar to that reported for "idiopathic" hemophagocytic syndrome ${ }^{2,3}$, with bone marrow, liver, spleen and lymph node involvement by hemophagocytosis. As it has been reported, there was no response to corticosteroids. Growth factors (G- CSF), as well as cytarabine in low doses were used with no response.

Reiner and Spivak ${ }^{3}$ evaluated 23 patients and performed an extensive review of the literature about hemophagocytic histiocytosis. According to these authors, this syndrome may not be rare. In their experience, among 2634 bone marrow cytological examinations, four cases with this syndrome were diagnosed per year $(0,7 \%)$. The increase in viral infections and neoplasias, and the refinement of diagnostic techniques, are likely to enhance the diagnosis of hemophagocytic syndrome. As studies of the relationships between immunological mediators progress, a better understanding of the pathophysiologic mechanisms underlying this syndrome may be achieved.

\section{RESUMO}

A síndrome hemofagocítica (SH) caracteriza-se por um quadro clínico de febre, hepatoesplenomegalia, linfonodomegalia e pancitopenia periférica. A fagocitose de elementos hematopoiéticos por macrófagos, morfologicamente normais, está na origem da síndrome. A SH é considerada rara, manifestando-se como uma doença primária, ou associada a vírus, a neoplasias ou a doenças auto-imunes. O tratamento é controverso e a sua evolução, muitas vezes é fatal. A avaliação anátomo-patológica, apresenta o fenômeno da hemofagocitose em diversos órgãos, incluindo, principalmente, os hematopoéticos.

Apresentamos os vários contextos clínicos no qual esta síndrome aparece, a importância do seu diagnóstico e o estudo da interação entre as citoquinas, as células imunorreguladoras e a terapêutica imunossupressora. Exemplificamos a síndrome hemofagocítica através de um caso clínico, com seus dados complementares, incluindo os necroscópicos.

\section{REFERENCES}

1. Eliopoulos G, Vaiopoulos G, Kittas C, Fessas P. Tuberculosis associated hemophagocytic syndrome complicated with severe bone marrow failure and disseminated intravascular coagulation. Nouv Rev Fr Hematol 1992;34:273 - 276.

2. Favara BE. Hemophagocytic Lymphohistiocytosis: A Hemophagocytic Syndrome. Sem Diagn Pathol 1992;9(1):63-74.

3. Reiner AP, Spivak JL. Hematophagocitic Histiocytosis. Medicine 1988;67:369-388

4. Granert C, Elinder G, Öst A; Henter J. Kala-azar in a oneyear-old Swedish child. Diagnostic difficulties because of active hemophagocytosis. Acta Pediatr 1993;82:794-796.

5. Kikuta H, Sakiyama Y, Matsumoto S, et al. Fatal EpsteinBarr Virus- associated Hemophagocytic Syndrome. Blood 1993;82:3259-3264.
6. Henter J, Elinder G, Söder O, Hansson M, Andersson B, Anderson U. Hypercytokinemia in Familial Haemophagocytic Lymphohistiocytosis. Blood 1991;78: 2918-2922.

7. Risdall RJ, Mckenna RW, Nesbit ME, et al. Virus-associated Hemophagocytic Syndrome. A Benign histiocytic proliferation distinct from malignant histiocytosis. Cancer 1979;44:993-1002.

8. Oyama Y, Amano T, Hirakawa S, Hironaka K, Suzuki S, Ota Z. Haemophagocytic Syndrome treated with Cylclosporin A. A T Cell disorder?. Br J Haematol 1989;73:276-278.

9. Tsuda H, Shirono K. Successful treatment of virus-associated haemophagocytic syndrome in adults by cyclosporin $\mathrm{A}$ supported by granulocyte colony-stimulating factor. $\mathrm{Br} \mathrm{J}$ Haematol 1996;93:572-575.

10. Shirono K, Isuda H. Parvovirus B19-associated haemophagocytic syndrome in healthy adults. Br J Haematol 1995;89:923-926. 
11. Cheng A, Su I, Chen Y, Uen W, Wang C. Characteristic Clinicopathologic Features of Epstein-Barr VirusAssociated Peripheral T-Cell Lymphoma. Cancer 1993;72:909-9163.

12. Jaffe ES, Costa J, Fauci AS, Cossman J, Tsokos M. Malignant Lymphoma and Erytrophagocytosis
Simulating Malignant Histiocytosis. Am J Med 1983;75:741-749.

13. Su I, Hsu Y, Lin M, Cheng A; Wang C, Weiss, LM. EpsteinBarr Virus- Containing T-Cell Lymphoma presents with Hemophagocytic syndrome Mimicking Malignant Histiocytosis. Cancer 1993;72:2019-2027. 